\title{
Budd-Chiari Syndrome: An Unusual Complication of AL Amyloidosis
}

\author{
Primer Amiloidozun Nadir Bir Karaciğer Tutulumu: Budd-Chiari Sendromu
}

\author{
(DTarık Onur Tiryaki¹, (D) Ipek Yönal Hindilerden 1, (D) Gülçin Yegen², (D) Meliha Nalçacı1 \\ 'istanbul University Istanbul Medical Faculty, Department of Internal Medicine, Division of Hematology, Istanbul, Turkey \\ 2istanbul University Istanbul Medical Faculty, Department of Pathology, istanbul, Turkey
}

To the Editor,

Budd-Chiari syndrome (BCS) is an uncommon congestive hepatopathy caused by blockage of hepatic veins in the absence of cardiac/pericardial disorders as well as hepatic veno-occlusive disease [1]. In 75\% of patients with BCS there is an underlying condition that predisposes to blood clotting [2]. More than one etiological factor may play a role in $25 \%$ of cases [2]. Coagulation problems mainly involving bleeding abnormalities are well recognized in $\mathrm{AL}$ amyloidosis while thrombosis is a less common feature [3]. Here, we report a rare case of $A L$ amyloidosis complicated by BCS.

A 66-year-old man presented with right upper abdominal pain. On physical examination, there was hepatomegaly measuring $6 \mathrm{~cm}$ below the costal margin. His complete blood count (CBC) was as follows: hemoglobin ( $\mathrm{Hb}), 11 \mathrm{~g} / \mathrm{dL}_{\text {; }}$ white blood

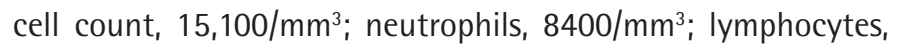
$4700 / \mathrm{mm}^{3}$; platelets, $677,000 / \mathrm{mm}^{3}$. The following biochemical tests were abnormal: corrected calcium, $10.74 \mathrm{mg} / \mathrm{dL}$ (normal range: 8.5-10.5); albumin, $3.12 \mathrm{~g} / \mathrm{dL}$ (normal=3.2-5.5); alkaline phosphatase, 266 IU/L (normal=35-105); gamma-glutamyl transferase, $388 \mathrm{IU} / \mathrm{L}$ (normal=5-85); C-reactive protein, 26 (normal=0-5); erythrocyte sedimentation rate, $85 \mathrm{~mm} / \mathrm{h}$ (normal=0-20). JAK2V617F mutation was not detected and bcr-abl was negative. Upon serum protein electrophoresis, a monoclonal protein of $0.01 \mathrm{~g} / \mathrm{dL}$ was present and serum and urine immunofixation electrophoresis showed monoclonal $\lambda$ light chain. Serological tests for hepatitis B, hepatitis C, HIV, and autoimmune liver disorders were negative. The result of the 24-h urine protein was $150 \mathrm{mg}$. Abdominal ultrasonography showed hepatomegaly measuring $189 \mathrm{~mm}$ on the longitudinal axis. Liver biopsy showed diffuse amyloid deposits in the parenchyma stained by Congo red (Figure 1). Bone marrow biopsy demonstrated increased plasma cells constituting $20 \%$ of the marrow cellularity and eosinophilic, homogeneous deposits of amyloid confirmed by Congo red staining. Echocardiography showed thickened interventricular septum measuring $15 \mathrm{~mm}$. Histological examination of the duodenum revealed amorphous pink deposits in the lamina propria staining positive for Congo red. The patient did not meet the diagnostic criteria for myeloma and was diagnosed with $\mathrm{AL}$ amyloidosis with kidney, heart, liver, and gastrointestinal tract involvement. CyBorD was initiated as induction treatment. After 1 course of CyBorD, his $C B C$ results were completely normal. After the $4^{\text {th }}$ course, the patient presented with severe acute right upper quadrant abdominal pain and severe orthostatic hypotension. Abdominal CT angiography showed thrombosis of the left and middle hepatic veins. Intrahepatic venous collaterals and a relative increase in the caudate and left lobes of the liver were noted (Figure 2). These findings were compatible with BCS. Screening

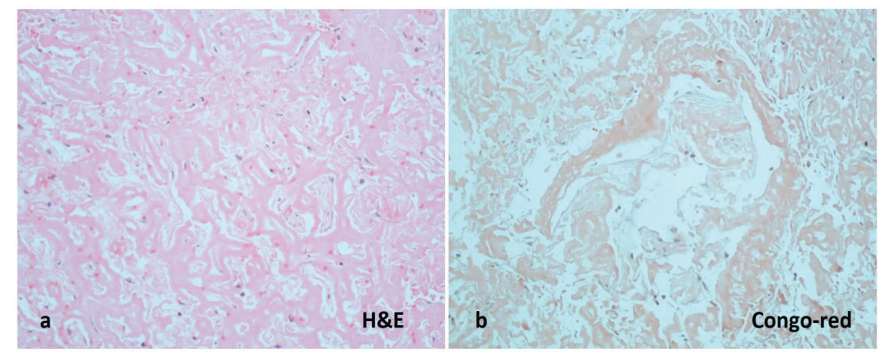

Figure 1. Diffuse infiltration of eosinophilic amorphous material in the liver parenchyma $\left(a, H \& E, 400^{x}\right)$, and deposition positive for Congo red staining $\left(b, 400^{x}\right)$.

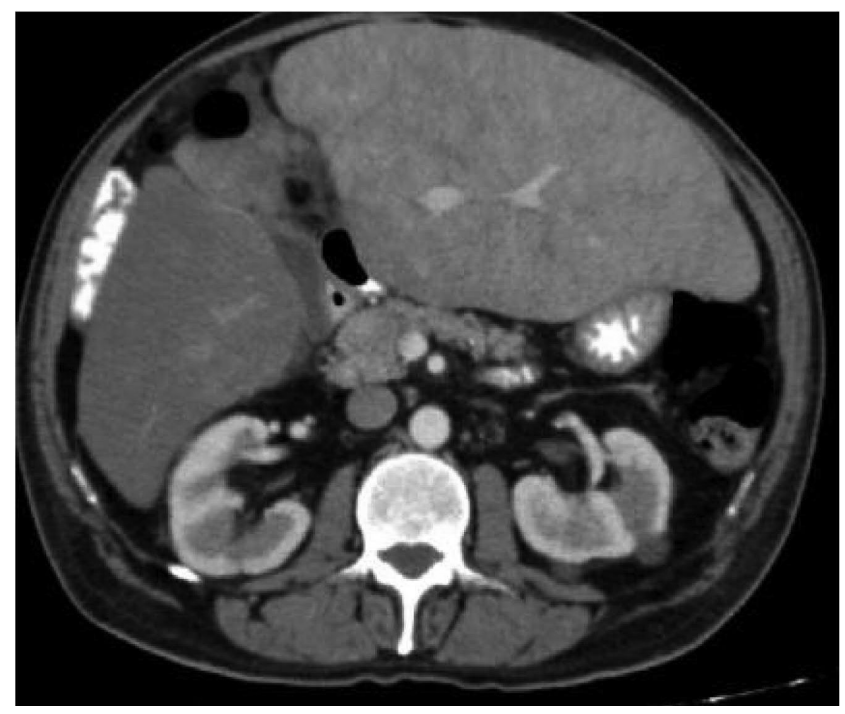

Figure 2. Abdominal CT angiography demonstrated occlusion of the left hepatic vein and enlargement in the left lobe of the liver. 
for hereditary and/or acquired thrombophilic conditions were negative. Anticoagulation with low-molecular-weight heparin was initiated.

To our knowledge, this is the first reported case of $A L$ amyloidosis complicated by BCS in the absence of nephrotic syndrome. The underlying causes of bleeding in $\mathrm{AL}$ amyloidosis are well established, including acquired factor $X$ deficiency, increased intravascular coagulation and fibrinolysis, and capillary infiltration by amyloid and liver involvement, which results in the reduced synthesis of procoagulant proteins $[4,5]$. Thrombosis is a less-recognized association of $\mathrm{AL}$ amyloidosis. It was demonstrated that impairment of the thrombin-antithrombin pathway, in association with low antithrombin biological activity, contributed to hypercoagulability in amyloidosis [5]. Cançado et al. [6] described a BCS patient diagnosed with AL amyloidosis in the concomitant presence of nephrotic-range proteinuria. The loss of hemostatic proteins due to nephrotic syndrome certainly contributed to the imbalance between clotting factors and inhibitors [6]. Although arterial thrombosis after bortezomib treatment has been reported rarely, a review of data from phase 3 trials demonstrated lower venous thromboembolism risk with bortezomib $[7,8]$. Therefore, we believe that there is no association between BCS and bortezomib. Our case shows that $\mathrm{AL}$ amyloidosis patients can develop BCS even in the absence of nephrotic syndrome.

Keywords: Primary amyloidosis, Budd-Chiari syndrome, Plasma cell diseases

Anahtar Sözcükler: Primer amiloidoz, Budd-Chiari sendromu, Plazma hücre hastalıkları

Compliance with Ethical Standards: The authors have no potential conflicts of interests to declare. This research includes human participants. Informed consent was obtained. All procedures performed in this study were in accordance with the ethical standards of the institutional and/or national research committee and with the 1964 Helsinki Declaration and its later amendments or comparable ethical standards. This study did not receive any funding.

Informed Consent: It was received.

\section{Authorship Contributions}

Data Collection or Processing: G.Y., M.N.; Writing: O.T.T., I.Y.H.

Conflict of Interest: No conflict of interest was declared by the authors.

Financial Disclosure: The authors declared that this study received no financial support.

\section{References}

1. Aydinli M, Bayraktar Y. Budd-Chiari syndrome: etiology, pathogenesis and diagnosis. World J Gastroenterol 2007;13:2693-2696.

2. Denninger $M H$, Chaït $Y$, Casadevall $N$, Hillaire $S$, Guillin MC, Bezeaud $A$, Erlinger S, Briere J, Valla D. Cause of portal or hepatic venous thrombosis in adults: the role of multiple concurrent factors. Hepatology 2000;31:587591.

3. Kyle RA, Gertz MA. Primary systemic amyloidosis: clinical and laboratory features in 474 cases. Semin Hematol 1995;32:45-59.

4. Kyle RA, Greipp PR. Amyloidosis (AL): clinical and laboratory features in 229 cases. Mayo Clin Proc 1983;58:665-683.

5. Gamba G, Montani N, Anesi E, Palladini G, Lorenzutti F, Perfetti V, Merlini G. Abnormalities in thrombin-antithrombin pathway in $\mathrm{AL}$ amyloidosis. Amyloid 1999;6:273-277.

6. Cançado GGL, Faria LC, Osório FMF, Vidigal PVT, Couto CA, Ferrari TCA. Budd Chiari syndrome associated with $\mathrm{AL}$ amyloidosis: a coagulation paradox. Amyloid 2018;25:70-71.

7. Guo HF, Su HL, Mao JJ, Sun C, Wang J, Zhou X. Stroke after treatment with bortezomib and dexamethasone in a Chinese patient with extramedullary relapse of multiple myeloma. Int J Clin Pharmacol Ther 2010;48:776-778.

8. Zangari $M$, Fink $L$, Zhan F, Tricot $G$. Low venous thromboembolic risk with bortezomib in multiple myeloma and potential protective effect with thalidomide/lenalidomide-based therapy: review of data from phase 3 trials and studies of novel combination regimens. Clin Lymphoma Myeloma Leuk $2011 ; 11: 228-236$.

๑Copyright 2020 by Turkish Society of Hematology

Turkish Journal of Hematology, Published by Galenos Publishing House

Address for Correspondence/Yazışma Adresi: Onur Tarık Tiryaki, M.D., İstanbul University İstanbul Medical

Faculty, Department of Internal Medicine, Division of Hematology, İstanbul, Turkey

Phone : +905062168695

E-mail : tonurtiryaki@gmail.com ORCID: orcid.org/0000-0002-0096-5684
Received/Geliş tarihi: May 12, 2019 Accepted/Kabul tarihi: February 28, 2020

DOI: 10.4274/tjh.galenos.2020.2019.0186 